\title{
Using light stable isotopes to understand nutrient cycling in soils and how these isotopic techniques can be leveraged to investigate the ecology and biology of insects - A review
}

\author{
Die Verwendung von leichten stabilen Isotopen zum Verständnis \\ des Nährstofflkreislaufes in Böden und über das Nutzbarmachen \\ dieser Isotopentechniken zur Erforschung der Ökologie und Biologie \\ von Insekten - Eine Übersicht
}

\author{
Rebecca Hood-Nowotny
}

University of Natural Resources and Life Sciences Vienna (BOKU), Department of Forest and Soil Sciences, Institute of Soil Research, KonradLorenz-Straße 24, 3430 Tulln, Austria; rebecca.hood@boku.ac.at

Received: 13 November 2017, received in revised form: 15 January 2018, accepted: 15 January 2018

\begin{abstract}
Summary
At first glance, there appears little to link nitrogen cycling with entomology other that the use of isotope techniques. Soil management requires a contextual, adaptive, flexible approach that is based on understanding the factors that regulate the soil's fundamental processes. Using stable isotope techniques for the analysis of the inherent biogeochemical processes can explain the complex soilplant interactions, the determining factors of the nitrogen cycle, and the impacts of applying external inputs. Using the same stable isotope tools enables an interdisciplinary collaboration between soil science and entomology. Emerging plant pests, for instance, non-native insect species, are a threat to the agroecosystems. The knowledge of the origin and movement of invasive insects by using the intrinsic stable isotope signatures embedded in the environment allows identification of entry pathways and thus the establishment of effective management strategies to reduce the potential crop damage. Moreover, the feeding and mating biology of insects can also be understood using isotope techniques. Finally, the movement of mosquitoes can be understood by isotopic labeling so that these dangerous disease vectors can be more effectively managed. This and further research has led to a fuller understanding of insect feeding ecology and leading neatly around to how insect nutrition impacts soil organic matter turnover.
\end{abstract}

Keywords: Soils, biogeochemistry, entomology, insects, nitrogen

\section{Zusammenfassung}

Auf den ersten Blick scheint den Stickstoffkreislauf wenig mit der Entomologie zu verbinden, mit Ausnahme des Gebrauches von Isotopentechniken. Bodenmanagement verlangt nach einem kontextbezogenen, anpassungsfähigen und flexiblen Denkansatz, der auf dem Verständnis der Faktoren, welche die grundlegenden Bodenprozesse regulieren, beruht. Die Verwendung der Stabile-Isotopen-Technik für die Analysen der inhärenten biogeochemischen Prozesse kann die komplexen Boden-Pflanzen-Beziehungen, die bestimmenden Faktoren des Stickstoffzykluses und den Einfluss von externem Input von organischer Masse erklären. Die Verwendung dieser Werkzeuge erlaubt eine interdiziplininäre Zusammenarbeit zwischen der Bodenforschung und der Entomologie. Neu auftauchende Pflanzenschädlinge, wie nicht heimische Insekten, sind eine Bedrohung für das Agrarökosystem. Die Kenntnis über die Herkunft und der Verbreitung dieser invasiven Insekten mittels der Verwendung der spezifischen Isotopensignatur, die in der Natur eingebettet ist, ermöglicht uns, sie effektiv handzuhaben und den Schaden, den sie unseren Kulturpflanzen zufügen, zu minimieren. Darüber hinaus kann die Ernährung und Fortpflanzungsbiologie durch die isotopische Markierung von Insekten verstanden werden. Auch die Verbreitung von Steckmücken kann durch die isotopische Markierung verstanden werden, damit kann dieser gefährliche Vektor effektiver gemanagt werden. Diese und weitere Ergebnisse haben zu einem breiteren Verständnis der Ernährungsbiologie und des Einflusses der Ernährung der Insekten auf den Umsatz der organischen Masse im Boden geführt.

Schlagworte: Böden, Biogeochemie, Entomologie, Insekten, Stickstoff 


\section{Stable isotopes}

The modern view of subatomic structure includes a veritable "nuclear zoo" of particles and forces, and in this context, it is sufficient to view atoms simply as being composed of a positively charged nucleus surrounded by shells of negatively charged (orbital) electrons. The nucleus contains protons and neutrons as its major components of mass. A proton carries a positive (elementary) charge and a neutron has no charge. An isotope of an element has the same atomic number (protons) but a different number of neutrons, leading to a different atomic weight; therefore, stable isotopes react almost chemically identically to the more common isotope, because they occupy the same place in the periodic table. Different rates of reaction at an enzymatic level can result in slight variations in isotopic composition in nature, and these natural signatures can be used in ecological studies to trace food web structure, migration patterns, feeding preferences, and so on. Studies of natural variations in naturally occurring isotopic signatures are commonly referred to as natural abundance studies. Studies in which artificially enriched isotopes are added to the system are known as enrichment studies.

Stable isotopes are naturally abundant in the environment; they are safe and non-radioactive and, therefore, do not decay, which make them useful natural tracers. For example, approximately $1 \%$ of the carbon in our diet is the stable isotope ${ }^{13} \mathrm{C}$, the rest is ${ }^{12} \mathrm{C}$; and about $0.4 \%$ of the nitrogen in our diet is ${ }^{15} \mathrm{~N}$, the rest is ${ }^{14} \mathrm{~N}$.

Stable isotope analysis is traditionally undertaken using isotope ratio mass spectrometry (IRMS), separating ionized isotopes based on their mass-to-charge ratio. There are a number of other successful spectroscopic techniques to measure stable isotopes, many of which are laser based.

Stable isotopes are particularly useful in environmental science, as they provide a means to follow pathways with minimal disturbance or impact to the natural system allowing holistic unperturbed systems to be studied. It is this ubiquitous utility of stable isotope tools that has meant that the research described has spanned the two disciplines of entomology and soil science and far further beyond.

\section{Measuring nitrogen cycle biogeochemical transformation processes using stable isotopes}

The nitrogen cycle is one of the most important biological cycles from an anthropogenic perspective in terms of crop production, ecosystem services, and greenhouse gas emissions
(Tilman et al., 2002). Nitrogen is a limiting factor to production in most agricultural and natural ecosystems (Galloway et al., 2008) and is essential to the survival of all life forms (Hood et al., 1999; Hood, 2001). The applications of nitrogen fertilizer and subsequent increases in crop production have supported continued growth, meeting global food demands over the past century (Fanzo et al., 2011; Hood, 2002b).

However, it should be noted that the massive anthropogenic input of nitrogen has also led to a number of environmental problems including ground water pollution, release of potent greenhouse gases such as $\mathrm{N}_{2} \mathrm{O}$, and coastal and terrestrial eutrophication, all of which have an impact on people's health, biodiversity, and ecosystems' function on a regional and global basis (Sutton et al., 2011).

\subsection{The soil nitrogen cycle}

Ultimately, all organic matter (OM) entering the soil is degraded from organic to inorganic forms, mineralized, by the soil microbial biomass (SMB) (Figure 1). Macrobiotic fauna or physical processes breakdown OM into particulate organic forms. The ensuing enzymatic depolymerization of the particulate organic nitrogen transforms the complex polymeric $\mathrm{N}$ into bioavailable, monomeric, dissolved organic nitrogen (DON) forms such as free amino acids (FAAs) and amino sugars (Schimel and Bennett, 2004; Jackson et al., 2008). DON is assimilated or immobilized by the SMB, where depending on the soil $\mathrm{N}$ status, $\mathrm{N}$ is eventually released as ammonium (ammonification) or rarely as nitrate (heterotrophic nitrification; Fierer 2001). The governing processes are microbial mineralization-immobilization, micro/mesofaunal grazingthe "microbial loop" (Coleman, 1994), or microbial cell death and damage due to desiccation or viral lysis (Birch, 1958; Bowatte et al., 2010). Direct grazing of OM by soil fauna may directly lead to $\mathrm{N}$ mineralization, as some fauna excrete ammonium, and grazing can lead to increases in soluble organic carbon (Kagata and Ohgushi, 2012). The resultant available ammonium is lost to the atmosphere, adsorbed, or further assimilated by different guilds of SMB for growth or for energy through the conversion of ammonium into nitrate (nitrification); the resultant inorganic nitrate or ammonium can be readily taken up by plants.

\subsection{A changing paradigm}

During the past two decades, there has been an important paradigm shift in our understanding of the nitrogen cycle. 
Up until the 1990s, non-isotopic net mineralization assays were the most widely used and available tools. The thinking was dominated by agriculturally trained soil scientists with the concept that $\mathrm{N}$ mineralization is the limiting step in $\mathrm{N}$ cycling, plants only take up inorganic nitrogen, and plants compete poorly with SMB for $\mathrm{N}$ and mop up excess nitrogen that exceeds microbial demand. It has since become apparent that net mineralization assays fail to capture the complexity of the processes taking place. A series of studies using ${ }^{15} \mathrm{~N}$ pool dilution assays have improved our understanding; for example, they have shown that gross rates of nitrification and ammonification can far exceed rates of net mineralization, as differences in net mineralization can be a product of changes in microbial immobilization, gross mineralization, $\mathrm{N}$ losses, or all the three (Hood et al., 2003).
In addition, it has been shown that heterotrophic nitrification can be a significant pathway in some ecosystems (Barraclough and Puri, 1995) and that uptake of organic N such as amino acids is possible in N-poor ecosystems and some agricultural systems where there are mycorrhizal-associated plants, (Näsholm et al., 2000; 2009). This demonstrates the importance of mycorrhizal fungi in organic $\mathrm{N}$ acquisition (Hodge et al., 2001), with the consequence of blurring the boundaries of plant-soil microbe interactions.

\subsection{Isotope dilution methodologies}

Underpinning this paradigm shift in the conceptualization of the nitrogen cycle, a number of pioneering experiments were performed using isotope dilution methodology. Al-

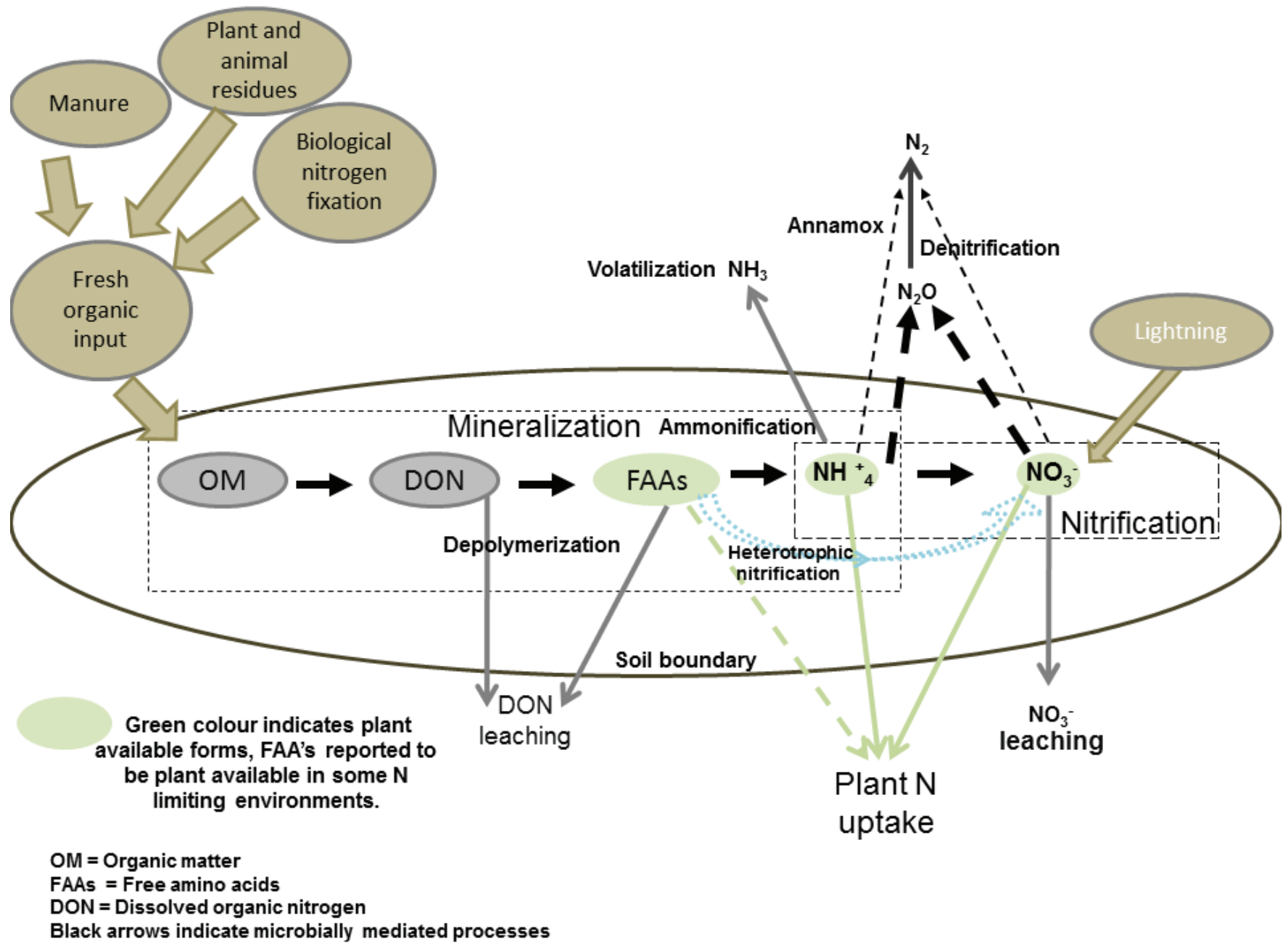

Figure 1. The soil nitrogen cycle Abbildung 1. Der Stickstoffkreislauf im Boden 
though these methods were available in 1958 (Kirkham and Bartholomew, 1958), it was only in the early 1990s, after the mathematics was deciphered and popularized by Barraclough (1991) and some methodological improvements were made, they were used routinely in soil science. The main issues that isotope dilution experiments address is the ability to measure individual process rates despite multiple fluxes and flows in and out of the measured pool, namely, the confounding processes of ammonification (inorganic $\mathrm{N}$ release from $\mathrm{OM}$ ), nitrification (conversion of ammonium to nitrate), immobilization (biological assimilation of available $\mathrm{N}$ ), nitrate leaching, and gaseous $\mathrm{N}$ losses (Hood et al., 2003). Using ${ }^{15} \mathrm{~N}$ isotope dilution, it is possible to study each transformation process independently (Barraclough, 1991; Watkins et al., 1996; Hood et al., 2003). Measures of independent transformation fluxes are conventionally referred to as gross fluxes, for example, gross nitrification, as opposed to net fluxes, which are the sum of all the above concurrent $\mathrm{N}$ processes. The principle of the isotope dilution technique (exemplified here for $\mathrm{N}$ mineralization) is that the ammonium pool is labeled with ${ }^{15} \mathrm{NH}_{4}^{+}$, then the ${ }^{15} \mathrm{~N}$ is diluted through the addition of unlabeled $\mathrm{N}$ from organic matter breakdown and the change in the ammonium pool size and isotope ratio are monitored (Barraclough, 1991; Kirkham and Bartholomew, 1954). From this, the amount of unlabeled $\mathrm{N}$ coming into the ammonium pool (gross mineralization) can be calculated. Using differential labeling of the ammonium and nitrate pool, both gross $\mathrm{N}$ mineralization and gross nitrification independent of other conflicting soil processes are determined (Hood and Wood, 1996; Watkins et al., 1996). Using these techniques, the microbial immobilization is measured and the parameters that drive the various independent processes are determined. One of the original underlying assumptions of the isotope dilution technique for measuring gross nitrogen mineralization rates in soils is that all organic to inorganic $\mathrm{N}$ transformations pass through the ammonium pool window prior to the uptake by microbial biomass, which is classically termed as the MIT route (mineralization-immobilization-turnover); this point was pivotally disproved by Barraclough (1997), who showed unequivocally that amino acids can be taken up directly by the microbial biomass (the direct route) and that both processes occur concurrently in most soils.

\subsection{Plant N uptake}

In agriculture, the availability of nitrogen from mineralization is ultimately our main interest as mineralization of soil organic matter (SOM) provides around $50 \%$ of the crop nitrogen in fertilized systems (Hood et al., 2003) and almost all the nitrogen in unfertilized systems. It is our understanding and management of the nitrogen cycle that has allowed us to keep with global demand for food (Hood, 2001), Be it through the efficient application of inorganic $\mathrm{N}$ fertilizer or the prudent application of manures or crop residues.

\subsection{Soil Fertility Management}

In a number of regions, the benefits of inorganic fertilizer usage have not been realized, because of social, environmental, and economic issues. Recent analysis of Sub-Saharan Africa suggests that fertilizer inputs are required to close yield gaps to within $50 \%$ of attainable yields (Mueller et al., 2012), although others have shown that this will be unachievable without additional soil water conservation strategies promoted through an integrated soil fertility management (ISFM) approach (Vondolia et al., 2012). In tropical countries, crop production is often constrained by the loss of SOM and the associated decline in soil fertility (Sanchez and Jama, 2002) evident from the negative net effect of agricultural production on soil fertility in Sub-Saharan Africa (Kimetu et al., 2008). In these regions, practices that include the use of fertilizer and organic input management in combination with improved germplasm have been promoted; however, methods to measure the mineralization and subsequent plant $\mathrm{N}$ uptake from complex residues are still lacking. Nitrogen and soil organic carbon management forms the foundation of this approach. Nitrogen is probably the most constraining nutrient in most cropping systems; thus knowledge of how efficiently both (i) inorganic nitrogen fertilizer is taken up by plants and (ii) complex organic nitrogen sources, such as manures or residues, are broken down and mineralized to crop available nitrogen is essential to develop effective soil management strategies, coherent with the know, understand, manage mantra. It was within this context that the following studies were carried out.

It is difficult to predict the availability of mineralized $\mathrm{OM}$ $\mathrm{N}$ to plants, because the processes of immobilization and mineralization, in addition to $\mathrm{N}$ losses, can occur simultaneously and are driven by a range of environmental parameters; moreover, in soils, there are high background concentrations of organic $\mathrm{N}$ that are mineralizing concurrently. ${ }^{15} \mathrm{~N}$ allows us to trace the path of nitrogen breakdown from organic $\mathrm{N}$ into inorganic $\mathrm{N}$ that is readily available to 
plants. There are a number of ${ }^{15} \mathrm{~N}$ isotope techniques available to follow the important nitrogen transformation processes in soil, direct isotope labeling techniques in which the material of interest is labeled with enriched isotopes and the isotope is traced into various pools, and indirect techniques in which a target pool is labeled with an isotope and the fluxes into that pool are calculated from the dilution of the isotope in the pool and the change in pool size. The direct techniques are the most reliable and simple techniques for measuring $\mathrm{N}$ release from organic residues; however, these methods can be extremely expensive or logistically difficult to implement for complex residues such as sewage sludge or waste materials. Thus indirect techniques have a specific scientific niche in studies of $\mathrm{N}$ dynamics. Indirect techniques can be used to study plant $\mathrm{N}$ uptake from organic residues or animal manures; however, precautions must be taken to avoid problems of pool substitution. The principle is that an inorganic ${ }^{15} \mathrm{~N}$ tracer is added to the soil and treatments with and without residues (no-residue controls) are set up. The no-residue control will have a ${ }^{15} \mathrm{~N}$ abundance that reflects the soil ${ }^{15} \mathrm{~N}$ pool enrichment, and the residue treatments generally have a lower ${ }^{15} \mathrm{~N}$ because of the input of the unlabeled $\mathrm{N}$ from mineralization of the unlabeled residue. In practice, the application of ${ }^{15} \mathrm{~N}$ label and residues at the same time has been shown to cause errors associated with pool substitution (Hood et al., 1999). Pool substitution is the process by which added labeled inorganic $\mathrm{N}$ (fertilizer) stands proxy for unlabeled inorganic soil $\mathrm{N}$ that would have otherwise been abstracted from a common pool that contains labeled and unlabeled N. It has been shown that the problem of pool substitution can be overcome if the soil is prelabeled with ${ }^{15} \mathrm{~N}$ and left to equilibrate for up to 6 months before the application of residues. This new approach was proposed, tested, and validated (Hood et al., 2000). It was hypothesized that if the soil was prelabeled with ${ }^{15} \mathrm{~N}$ and a suitable carbon source, it should be possible to uniformly isotopically label the soil, which could then be subsequently used for further isotope dilution experiments without running into the problems of pool substitution. Field trials to test simple prelabeling approach were set up, in which a plot that had been labeled in the year prior to the experiments by applying labeled fertilizer to the plot and then removing the above ground plant material. This was tested against the direct methodology using a mirror image experimental set up in which ${ }^{15} \mathrm{~N}$-labeled residues were added to unlabeled plots and identical in all but the label. ${ }^{14} \mathrm{~N}$ residues were added to prelabeled plots and $\mathrm{N}$ uptake in a maize crop measured (Hood et al., 2003). This allowed us to compare the direct and indirect approaches for measuring $\mathrm{N}$ release from organic residues directly. Having obtained similar values using both approaches, it was clear that the method was suitable for measuring $\mathrm{N}$ release from more complex residues such as manures; this was again tested in the field and compared against direct approach controls (Hood, 2002a). Additional experiments to compare the methods and study the dynamics of $\mathrm{N}$ release from the manures and residues by determining the gross mineralization and nitrification rates in the soil were also undertaken; these experiments demonstrated that there was an initial flush of $\mathrm{N}$ release from particularly turkey manure and yielded some insight into the $\mathrm{N}$ cycling processes (Hood et al., 2003).

\subsection{Dissolved organic nitrogen}

The Paradigm Shift has led to an awareness of the role ofDON in plant nutrition in natural ecosystems and has formed the basis of thinking in which ammonification of $\mathrm{OM}$ to $\mathrm{NH}_{4}^{+}$ loses central focus and is replaced by a more holistic twostep definition that encompasses depolymerization of DON followed by ammonification of DON, in which depolymerization has been viewed as the rate-limiting step. To what extent the new paradigm is relevant to $\mathrm{N}$ replete agricultural systems is still to be tested, but the new concept allows an overarching understanding of soil processes irrespective of whether they are natural or agricultural. Taking into account the new paradigm, studying of nitrogen dynamics will require simultaneous measurements of a number of nitrogen pools that can be laborious and time consuming, leading to logistical and experimental constraints that fail to capture the complexity of the processes studied. It was with these considerations in mind that we set out to develop a suite of methods that would allow rapid and simultaneous analysis of not only the inorganic $\mathrm{N}$ pools but also the soluble organic soil nitrogen pools and would allow expansion of the logistical scope of our experiments. Fundamentally, the methods are based on a number of published reactions; however, it is their novel configuration and adoption of a microtiter plate measurement platform that provides both the innovation and ease of use (Hood-Nowotny et al., 2010). Indeed, the adoption of simple computer scanners combined with image analysis software could render these methods universally available doing away with the need for expensive microtiter plate readers (Harris et al., 2009). 


\section{The use of stable isotopes in entomological research}

Insect pests cause economic losses in the order of billions in addition to untold human suffering. One method for controlling and eradicating insect pests is the sterile insect technique (SIT). SIT is the repeated overflooding of natural populations with sterile individuals such that the resident population is eventually eradicated. Sterilization can be achieved chemically, genetically, or through gamma irradiation from either solid-state gamma source or X-ray. Knowing the ratio of sterile to wild population is one of the key issues in SIT operations, and having a simple marker to trace the movement and populations of insects is essential to understand the insect ecology.

\subsection{Marking of insects}

Conventional marking methods for mosquitoes such as the use of fluorescent dusts are not suitable for such small, heavily predated insects. Given mosquitoes' small size and simple mass rearing conditions, an enriched isotope marker presented itself as an appropriate solution. Although both ${ }^{13} \mathrm{C}$ and ${ }^{15} \mathrm{~N}$ marking were tested initially, ${ }^{15} \mathrm{~N}$ abundances in the natural environment are somewhat constrained and it was felt that ${ }^{13} \mathrm{C}$ would be a more reliable marker. The labeling and persistence of the label of mass-reared mosquitoes was tested and the information on the rate of carbon turnover in the mosquito was also established using simple isotopic models (Hood-Nowotny et al., 2006). The feasibility of using the stable isotope of carbon, ${ }^{13} \mathrm{C}$, as a potential intrinsic chemical marker for Anopheles arabiensis was evaluated. ${ }^{13} \mathrm{C}$-labelled glucose was incorporated into the larval diet. The contribution of adult sugar feeding to the total mosquito carbon pool and the metabolically active carbon pool was determined by tracing the decline of the ${ }^{13} \mathrm{C}$ enrichment of the adult male mosquito as it switched from a labeled larval diet to an unlabeled adult diet. This decline in the adult was monitored by destructive sampling of the whole mosquito. A two-pool model was used to describe the decline of the ${ }^{13} \mathrm{C}$-enrichment of adult mosquitoes. The proportion of the total adult carbon pool derived from the adult sugar diet over the life span of mosquitoes was determined, and the ratio of structural carbon, with a low turnover rate in relation to metabolically active nonstructural carbon, was assessed. The uptake and turnover of sugar in the metabolically active fraction suggest that after 3 days, more than $70 \%$ of the active fraction carbon is derived from sugar feeding (increasing to $>90 \%$ by day 7 ), indicating the high resource demand of male mosquitoes. It was possible to "fix" the isotopic label in adult $A$. arabiensis and to detect the label up to 21 days post-emergence, proving it to be a reliable intrinsic marker.

\subsection{Competition studies}

Another key issue in SIT research is the ability of irradiated sterile males to compete for wild females, as the success of the whole program depends on the male's ability to win the wild female and subsequently mate with her, preventing the production of subsequent generations (Figure 2). Usually laborious egg counts are combined pitching steriles against non-steriles in various ratios. By labeling the male mosquitoes with isotopes, it is possible to directly trace the transfer of sperm from males to females unambiguously (Figure 3; Helinski et al., 2007). This method worked extremely well despite a number of methodological barriers that we had to overcome such as the tiny mass of the female spermathacae, which means that we had to spike the samples to attain sufficient material for isotope analysis. The potential of the use of stable isotopes to study mosquito mating was investigated by tracing the fate of ${ }^{13} \mathrm{C}$-isotope-labeled semen into spermathacae. ${ }^{13} \mathrm{C}$-labeled glucose was incorporated in the diet of the mosquito $A$. arabiensis. The results demonstrated that labeled spermathacae positive for semen could successfully be distinguished from empty ones or controls (i.e., filled with unlabeled semen) using the isotopic data. There were no negative effects of the addition of labeled glucose on larval development and survival, adult size, male longevity, and mating performance (Figure 4). We demonstrated that it was possible to label male mosquitoes and detect the semen label in female spermathacae after insemination. This has proved useful in other insects such as moths and has shown to be useful in genetic control studies of medical or agricultural pest insects, with male mating success in the field as a critical verifiable indicator for a positive outcome of the intervention.

\subsection{Opportunities for further development of isotope techniques in the entomological field}

There is a wealth of untapped potential for the use of isotopes in entomological research; this was reviewed by Hood-Nowotny and Knols (2007). This paper demonstrated that stable isotopes can be used to understand fun- 
Who's mating who? The ultimate test of insect quality

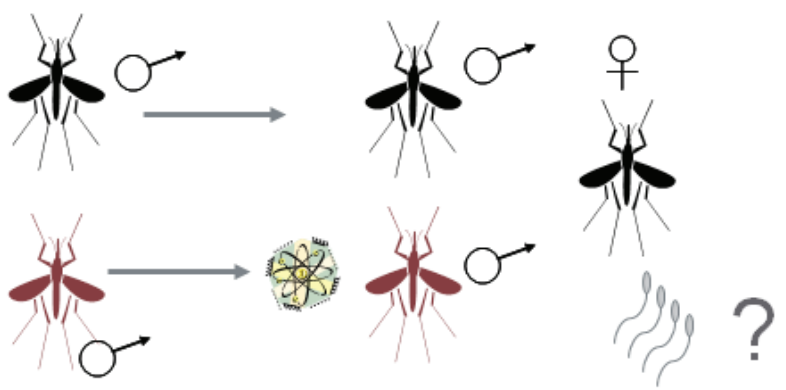

Figure 2. Schematic of the sterile insect technique (SIT) and the problem of determining who is mating who, as if a sterile male insect mates with the fertile female it is almost impossible to determine who has fathered the subsequent eggs as these are sterile. Using isotope labeling provides an answer to these questions.

Abbildung 2. Prinzip der Sterile-Insekten-Technik (SIT) und dem Problem der Bestimmung, wer wenn begattet. Denn wenn ein steriles männliches Insekt ein fertiles weibliches begattet, ist es fast unmöglich zu bestimmen, wer die daraus entstehenden Eier gezeugt hat, da diese steril sind. Durch die Isotopenmarkierung kann eine Antwort auf diese Fragen gegeben werden.

damental processes in the biology and ecology of arthropods, which range from nutrition and resource allocation to dispersal, food-web structure, predation, and so on. It was highlighted that falling costs and reduced complexity of isotope analysis, besides the emergence of new analytical methods, would popularize the methods still further as history has shown.

A number of entomological isotope opportunities were explored; one of the particular cadences was the work on total body nitrogen and carbon turnover in fruit flies, as this levered isotope dilution equations derived directly from soils research into insect nutrition research. Using these techniques, it was possible to determine the intake and excretion of nitrogen at microgram scale in fruit fly, allowing us to understand some fundamental processes in fruit fly development and nutrition (ul Haq et al., 2010). Nitrogen assimilation and turnover in the flies were measured using stable isotope ${ }^{15} \mathrm{~N}$ dilution techniques. Yeast incorporation into the diet significantly increased male body weight, total body carbon (TBC), and total body nitrogen (TBN) as compared to sugar-fed males. Female flies had significantly higher body weight, TBC, and TBN when compared with all males. TBC and TBN showed age-dependent changes, increasing until the age of sexual maturity and decreasing afterwards in both sexes. Methoprene treatment did not significantly affect TBC or TBN. The progressive increase of TBC with age suggests that lipogenesis occurs in adult male Bactrocera cucurbitae, as is the case in other tephritids. Stable isotope pool dilution was shown to be an effective method for determining $\mathrm{N}$ uptake in $B$. cucurbitae. This technique was used to show that sugar-fed males rely solely on larval $\mathrm{N}$ reserves and that the $\mathrm{N}$ uptake rate in males with access to diet including hydrolyzed yeast was higher shortly after emergence and then stabilized. One of the main highlights of this research was the role of protein assimilation in the initiation of lipogenesis.

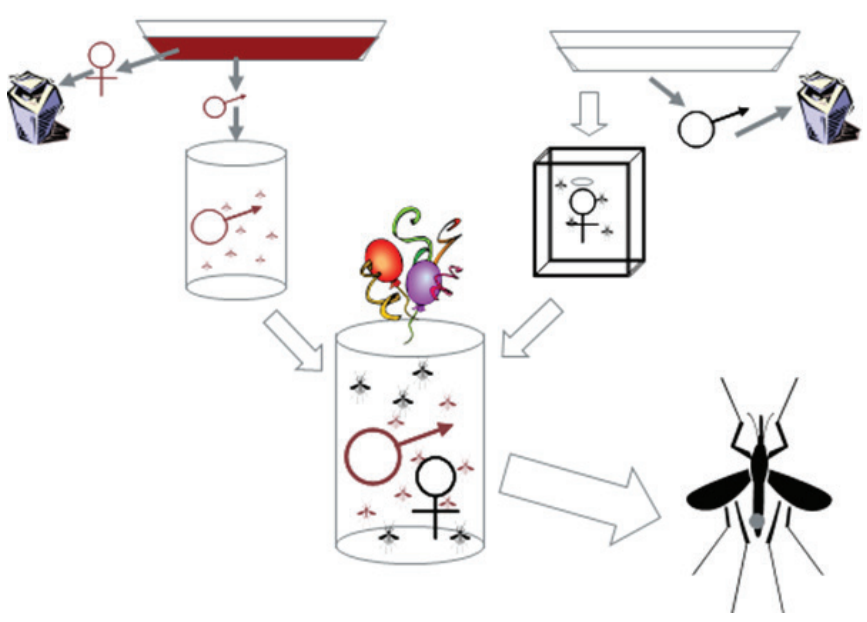

Figure 3. The sperm transfer from male to female mosquitoes can be measured by isotope labeling. One set of mosquitoes are isotopically labeled (represented by the red color); the labeled females are discarded and another set of males are raised naturally. Then, the isotope-labeled sperm is traced from the males into the unlabeled female's spermathacae. In the real experiments, both differentially treated (either fertile or sterilized and regular or labeled) male mosquitoes are added to the cage and compete for the females to determine the impacts of the sterilization process on the mosquito's ability to mate with the females.

Abbildung 3. Der Spermientransfer von männlichen zu weiblichen Stechmücken kann durch die isotopische Markierung gemessen werden. Ein Satz von Stechmücken ist isotopisch markiert (in roter Farbe dargestellt), die markierten Weibchen werden verworfen und ein weiterer Satz an Männchen wird natürlich großgezogen. Dann wird das isotopisch markierte Sperma des Männchen in die nicht markierte Spermathek des Weibchen verfolgt. Im realen Experiment werden verschieden behandelte (entweder fertile oder sterile und normale oder markierte) männliche Stechmücken in den Käfig gesetzt und konkurrieren um die Weibchen, um den Einfluss des Sterilisationsprozesses auf die Fähigkeit der Stechmücke, sich mit Weibchen zu paaren, zu bestimmen. 


\section{Using labelled ${ }^{13} \mathrm{C}$ to trace sperm transfer.}
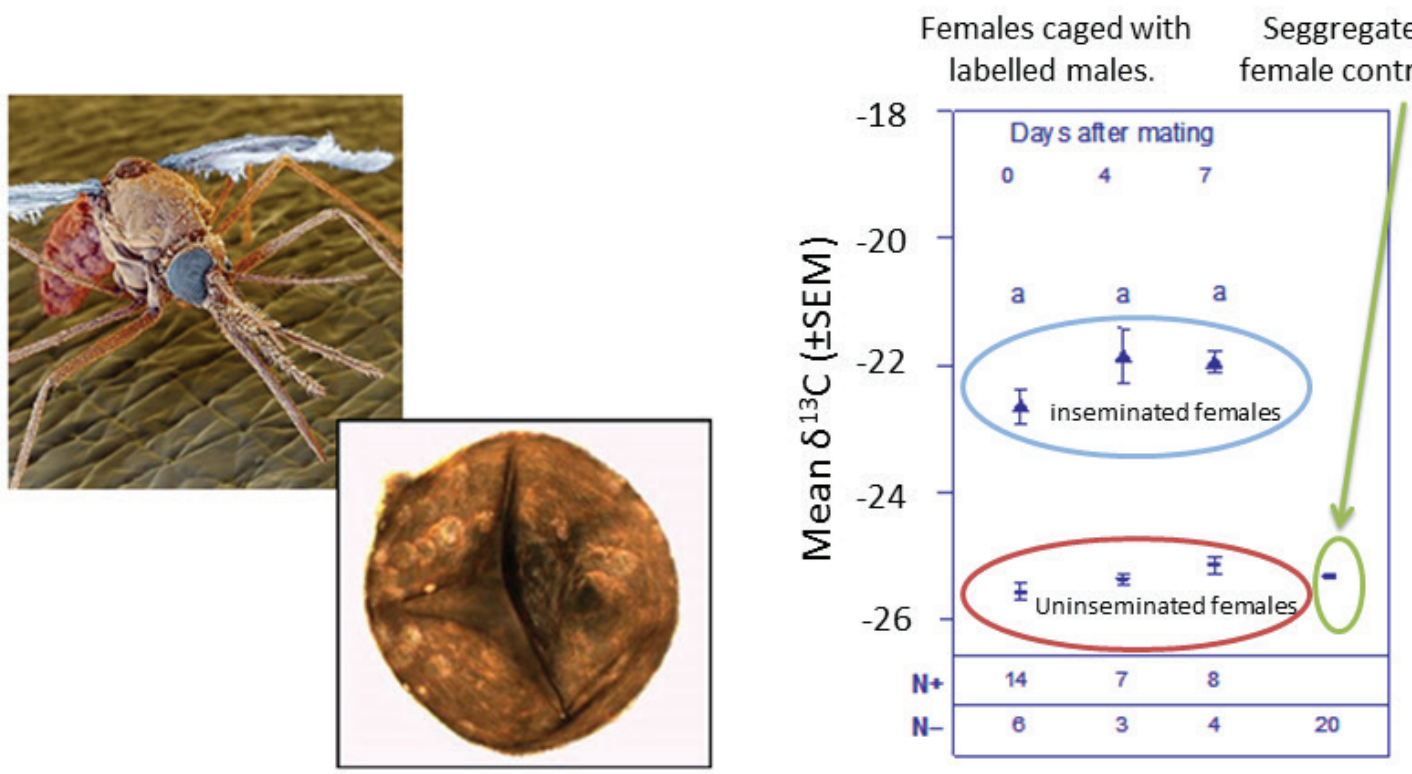

Figure 4. Results of ${ }^{13} \mathrm{C}$ labeling to trace sperm transfer. From left to right: a mosquito, a female's spermathacae, and the results from an experiment. In this experiment, female mosquitoes were inseminated (upper triangles) by ${ }^{13} \mathrm{C}$ isotopically labeled males or not inseminated (lower bold lines). $\mathrm{N}+$ is the number of analyzed inseminated females and $\mathrm{N}$ - is the number of uninseminated females as determined by microscopy. Segregated female control is the average isotopic abundance of spermathacae in females that had no contact with males and were raised on regular diets. All isotope values are referred back to international isotope standards, and error bars are standard error of the mean.

Abbildung 4. Ergebnisse der ${ }^{13} \mathrm{C}$ Markierung für die Nachverfolgung des Spermientransfers. Von links nach rechts: eine Steckmücke, eine weibliche Spermathek und die Ergebnisse des Experiments. In diesem Experiment wurden weibliche Moskitos durch ${ }^{13} \mathrm{C}$ isotopisch markierte Männchen inseminiert (obere Dreiecke) oder nicht inseminiert (untere fette Linien). N+ ist die Anzahl an analysierter inseminierter Weibchen und N-ist die Anzahl an analysierter nicht inseminierter Weibchen (Bestimmung mittels Mikroskopie). Die abgetrennte weibliche Kontrolle gibt die durchschnittliche Häufigkeit von Spermatheken bei Weibchen an, die keinen Kontakt zu Männchen hatten und mit normalem Futter großgezogen wurden. Alle Isotopenwerte beziehen sich auf internationale Isotopenstandards, Fehlerbalken sind die Standardfehler der Mittelwerte.

\subsection{Developing novel techniques to understand mosquito nutrition}

Having made initial inroads into insect nutrition driven from an agricultural production mindset, studies were set up to explore the nutritional factors controlling mosquito growth. This work explored both the stoichiometry and fatty acid (FA) composition of mosquito's diets and the mosquitoes reared on the diets revealing a number of important considerations for mosquito rearing and control (Hood-Nowotny et al., 2012). The principle factors controlling the population size and fecundity of mosquitoes are for the most part unknown. Larval habitat and diet play a crucial role in the subsequent fitness of mosquitoes. Developing the most competitive insects for SIT programs requires a "production"-orientated perspective; the information gained from this process offers us insight into mosquito physiology. FA profiles and de-novo or direct assimilation pathways of whole-individual mosquitoes reared on a variety of larval diets was determined using pyrolysis gas chromatograph/mass spectrometry. We assessed the impact of dietary quality on the stoichiometry, size, quality, and isotopic signatures of the subsequent population. The studies showed that diet had the greatest impact on FA profiles of the mosquitoes, which exhibited a high degree of dietary routing, characteristic of more generalist feeders (Figure 5). De-novo synthesis of a number of important FAs was observed. The C: $\mathrm{N}$ stoichiometry of the mosquito was fixed in the teneral stage. Dietary $\mathrm{N}$ content had a significant influence on the size of mosquito, and $\mathrm{P}$ was 
shown to be a flexible pool that limited the overall population size. These findings have significant implications for overall mosquito competitiveness and environmental management in both urban and rural contexts.

\section{Linking nitrogen cycling and entomology with stable isotopes}

At first glance, there appears little to link nitrogen cycling with entomology other that the leverage of the knowledge and methods used in soil science into entomology. However, because of the crossover and consistent backtracking across the disciplines, the role of soil arthropods in nitrogen mineralization has become increasingly apparent. The role of predators as a control point in the rhizosphere has been stressed (Moore et al., 2003), either through nutrient enrichment models or through alteration of symbiotic mutualistic interactions. The nutrient enrichment model shows how the role of soil predators can have consequences far beyond the plant-rhizosphere subsystem. In the nutrient enrichment model, plants exude exudates and stimulate growth and the microbes use the exudates and nitrogen in the soil which in turn prompts and increases in consumers and their predators. Plant growth increases due to an increase in nitrogen that is available to plant, with two con-
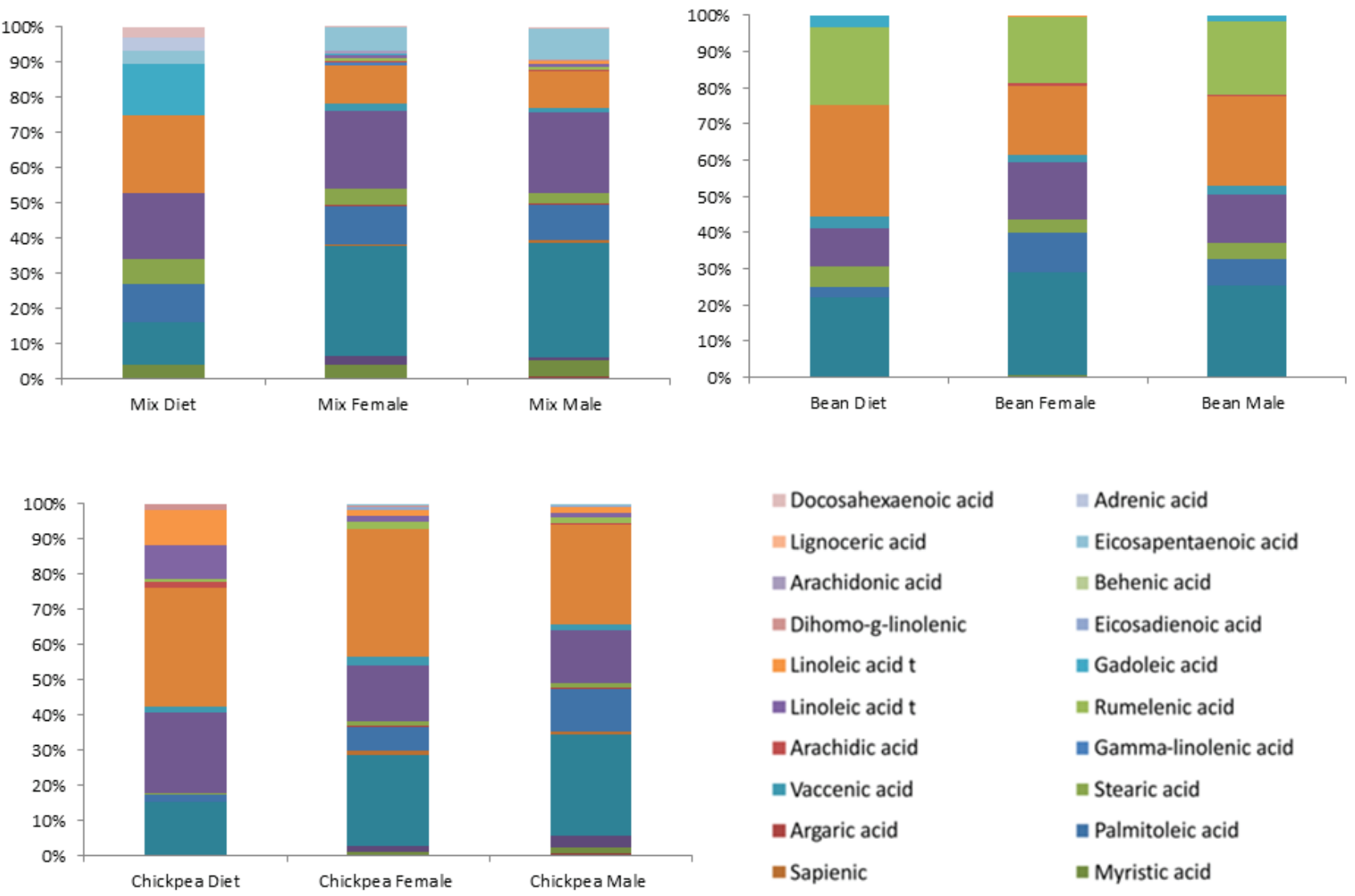

= Docosahexaenoic acid
= Lignoceric acid
= Arachidonic acid
= Dihomo-g-linolenic
= Linoleic acid t
= Linoleic acid t
= Arachidic acid
= Vaccenic acid
= Argaric acid
= Sapienic
- Lauric acid

" Adrenic acid
= Eicosapentaenoic acid
= Behenic acid
= Eicosadienoic acid
= Gadoleic acid
= Rumelenic acid
= Gamma-linolenic acid
= Stearic acid
= Palmitoleic acid
= Myristic acid
= Caprylic acid.

Figure 5. Percentage of relative abundance of fatty acids of the diet and the resulting female and male mosquitoes reared on that diet. The profiles are average of three replicate mosquitoes. In essence, this graph shows that for mosquitoes at least, you are essentially what you eat and that the fatty acid profile of the diet is directly retained in the adult form.

Abbildung 5. Prozentuelle relative Häufigkeit der Fettsäureprofile des Futters und der damit gefütterten männlichen und weiblichen Steckmücken. Die Profile sind Mittelwerte von drei Wiederholungen. Die Kernaussage dieser Graphik ist, dass das Fettsäureprofil des Futters direkt im erwachsenen Tier wiedergefunden werden kann. 
current consequences: the stimulation of microbial growth rates due to grazing and excretion of excess nitrogen. This model is supported by substantial experimental evidence (Hunt et al., 1987; Ruiter et al., 1993; Bardgett and Chan, 1999). The models predict that approximately $25-37 \%$ of total net $\mathrm{N}$ mineralization is attributable to soil fauna activity and assume $\mathrm{C}: \mathrm{N}$ ratio of predator prey remain constant irrespective of the quality of the input OM. Interestingly, the positive feedback between nutrient availability and carbon use efficiency has been implemented in only a few biogeochemical models (Manzoni et al., 2012). It has been shown that in nitrogen replete systems, carbon use efficiency in adult insects is higher, leading to higher $\% \mathrm{~N}$ in consumer excrement or frass (Kagata and Ohgushi, 2012). The work on fruit flies showed that fruit flies cycle $\mathrm{N}$ rapidly when there is sufficient available $\mathrm{N}$ and exhibit significant $\mathrm{N}$ retention mechanisms when $\mathrm{N}$ is limiting (ul Haq et al., 2010), underpinning the link between $\mathrm{N}$ availability and growth as opposed to maintenance activity when only carbon is supplied (Boberg et al., 2011) . Other works on actively growing larvae showed that there was a strong mass scaling component with greater insect size leading to proportionately lower $\mathrm{N}$ flux (Meehan and Lindroth, 2007) and that $\mathrm{N}$ flux is strongly increasing with temperature, suggesting that plant growth in natural ecosystems is in fact regulated by the relative importance of top-down control. Given these factors, it is posited that the role of grazers in soil nitrogen mineralization has been significantly underestimated, in part due to the methodological difficulties in testing the hypotheses in such small players in the system.

\section{Future research and outlook}

The importance of top-down control is in contrast to classical theory. Classical theory suggests that in terrestrial ecosystems, macrofauna, mesofauna, and SMB as members of detritus-based food webs play a key role in determining $\mathrm{N}$ cycling rates. The rate of $\mathrm{N}$ supply flows back up the plant-based food chain to control the level of primary and secondary productivity and community structure. However the emerging evidence increasingly emphasizes the importance of carnivores and herbivores in controlling $\mathrm{N}$ cycling in plant-based food-chains. Indeed archetypal approaches usually consider how plant based food-webs influence belowground species and associated processes through biomass inputs of detritus to soil. However, more recent insights into the interactions between detri- tus- and plant-based species suggest that top-down effects (Buchkowski and Schmitz, 2015) maybe be propagated through predator-driven changes in the feeding behavior of herbivores, which in-turn influences the composition of the plant community and, hence, plant inputs to the soil through litter fall or root exudation.

It should be possible to gain better insight into the role of soil fauna on soil nitrogen mineralization, given the advent of tools such as isotope dilution to measure gross $\mathrm{N}$ mineralization, quantitative real-time PCR qPCR, and the Barcode of Life to identify key players, in (addition) to FA tracing and isotope techniques that allow the accurate measurement of carbon and nitrogen use efficiencies, combined with modeling approaches. This is of upmost importance, given the global changes in nutrient status; elevated atmospheric reactive $\mathrm{N}$ deposition could result in a chain reaction of interacting microbial mechanisms, which in turn could lead to the shifts in underlying ecosystem biogeochemical process rates. It is hoped that with a combination of these techniques, scientists will be able to understand how these regional scale trends impact on soil carbon storage, which in turn should allow effective management of the earth's resources.

Understanding the interactions and feedbacks of insect herbivory and the influence of insects on detrital decomposition is urgently needed to understand the impact of species composition on $\mathrm{N}$ cycling in natural ecosystems. However, this urgency is in fact driven by the need to better understand the role of nitrogen cycling in the accumulation and turnover of carbon and its influence on global carbon stocks in light of climate change.

\section{References}

Bardgett, R.D. and K.F. Chan (1999): Experimental evidence that soil fauna enhance nutrient mineralization and plant nutrient uptake in montane grassland ecosystems. Soil Biology and Biochemistry 31, 1007-1014.

Barraclough, D. (1991): The use of mean pool abundances to interpret ${ }^{15} \mathrm{~N}$ tracer experiments. Plant and Soil 131, 89-96.

Barraclough, D. (1997): The direct or MIT route for nitrogen immobilization: A ${ }^{15} \mathrm{~N}$ mirror image study with leucine and glycine. Soil Biology and Biochemistry 29, 101-108.

Barraclough, D. and G. Puri (1995): The use of ${ }^{15} \mathrm{~N}$ pool dilution and enrichment to separate the heterotrophic 
and autotrophic pathways of nitrification. Soil Biology and Biochemistry 27, 17-22.

Birch, H.F. (1958): The effect of soil drying on humus decomposition and nitrogen availability. Plant and Soil 10, 9-31.

Boberg, J.B., Näsholm, T., Finlay, R.D., Stenlid, J. and B.D. Lindahl (2011): Nitrogen availability affects saprotrophic basidiomycetes decomposing pine needles in a long term laboratory study. Fungal Ecology 4, 408416.

Bowatte, S., Newton, P.C.D., Takahashi, R. and M. Kimura (2010): High frequency of virus-infected bacterial cells in a sheep grazed pasture soil in New Zealand. Soil Biology and Biochemistry 42, 708-712.

Coleman, D.C. (1994): The microbial loop concept as used in terrestrial soil ecology studies. Microbial Ecology 28, 245-250.

Buchkowski, R.W. and O.J. Schmitz (2015): Detritivores ameliorate the enhancing effect of plant-based trophic cascades on nitrogen cycling in an old-field system. Biology Letters 11, 20141048.

Fanzo, J., Remans, R. and P. Sanchez (2011): The Role of Chemistry in Addressing Hunger and Food Security. In: Garcia-Martinez, J. and E. Serrano-Torregrosa (Eds.): The Chemical Element: Chemistry's Contribution to Our Global Future. $1^{\text {st }}$ ed., Wiley-VCH, Weinheim, 71-97.

Fierer, N., Schimel, J.P., Cates, R.G. and J. Zou (2001): Influence of balsam poplar tannin fractions on carbon and nitrogen dynamics in Alaskan taiga floodplain soils. Soil Biology and Biochemistry 33, 1827-1839.

Galloway, J.N., Townsend, A.R., Erisman, J.W., Bekunda, M., Zucong, C., Freney, J.R., Martinelli, J., Seitzinger, S.P. and M.A. Sutton (2008): Transformation of the nitrogen cycle: Recent trends, questions, and potential solutions. Science 5878, 889-892.

Harris, H.H., Soldat, D.J., Barak, P. and B.J. Lepore (2009): Microscale colorimetric analysis using a desktop scanner and automated digital image analysis. Journal of Chemical Education 86, 617-620.

Helinski, M.E., Hood-Nowotny, R., Mayr, L. and B.G Knols (2007): Stable isotope-mass spectrometric determination of semen transfer in malaria mosquitoes. Journal of Experimental Biology 210, 1266-1274.

Hodge, A., Campbell, C.D. and A.H. Fitter (2001): An arbuscular mycorrhizal fungus accelerates decomposition and acquires nitrogen directly from organic material. Nature 413, 297-299.
Hood, R. (2002a): Plant N uptake from plant and animal organic residues, measured using the soil pre-labelling ${ }^{15} \mathrm{~N}$ isotope dilution approach. In: Vanlaauwe, B., Diels, J., Sanginga, N. and R. Merckx (Eds.): Integrated Plant Nutrient Management in Sub-Saharan Africa. CABI, Wallingford, 123-131.

Hood, R.C. (2001): The role of stable isotopes in reaching sustainability in the nitrogen cycle. In: Calbo, J., Pardini, G. and M. Rigola (Eds.): The nitrogen cycle and sustainability: A multidisciplinary approach. Divertas 19, Universitat de Girona, Spain, 131-147.

Hood, R.C. (2002b): The use of stable isotopes in soil fertility research. In: Krishna, K.R. (Ed.): Soil Fertility and Crop Production. Science Publishers Inc., Enfield, New Hampshire, 314-335.

Hood, R., Bautista, E. and M. Heiling (2003): Gross mineralization and plant $\mathrm{N}$ uptake from animal manures under non- $\mathrm{N}$ limiting conditions, measured using ${ }^{15} \mathrm{~N}$ isotope dilution techniques. Phytochemistry Reviews 2, 113-119.

Hood, R.C., Goran, K.N., Aigner, M. and G. Hardarson (1999): A comparison of direct and indirect ${ }^{15} \mathrm{~N}$ isotope techniques for estimating crop $\mathrm{N}$ uptake from organic residues. Plant and Soil, 259-270.

Hood, R., Merckx, R., Jensen, E.S., Powlson, D., Matijevic, M. and G. Hardarson (2000): Estimating crop N uptake from organic residues using a new approach to the ${ }^{15} \mathrm{~N}$ isotope dilution technique. Plant and Soil 223, $33-44$.

Hood, R. and M. Wood (1996): Estimating gross mineralisation of Alnus glutinosa residues, using ${ }^{15} \mathrm{~N}$ mirror image experimentation. In: Van Cleemput, O., Hofman, G. and A. Vermoesen (Eds.): Progress in Nitrogen Cycling Studies. Kluwer Academic Publishers, Dordrecht, The Netherlands, 53-56.

Hood-Nowotny, R., Hinko-Najera Umana, N., Inselbacher, E., Oswald-Lachouani, P. and W. Wanek (2010): Alternative methods for measuring inorganic, organic, and total dissolved nitrogen in soil. Soil Science Society of America Journal 74, 1018-1027.

Hood-Nowotny, R. and B.G.J. Knols (2007): Stable isotope methods in biological and ecological studies of arthropods. Entomologia Experimentalis et Applicata 124, 3-16.

Hood-Nowotny, R., Mayr, L. and B.G.J. Knols (2006): Use of carbon-13 as a population marker for Anopheles arabiensis in a sterile insect technique (SIT) context. Malaria Journal 5, 6. 
Hood-Nowotny, R., Schwarzinger, B., Schwarzinger, C., Soliban, S., Madakacherry, O., Aigner, M., Watzka, M. and J. Gilles (2012): An analysis of diet quality, how it controls fatty acid profiles, isotope signatures and stoichiometry in the malaria mosquito Anopheles arabiensis. PLoS ONE 7, e45222.

Hunt, H.W., Coleman, D.C., Ingham, E.R., Ingham, R.E., Elliott, E.T., Moore, J.C., Rose, S.L., Reid, C.P.P. and C.R. Morley (1987): The detrital food web in a shortgrass prairie. Biology and Fertility of Soils 3, 57-68.

Jackson, L.E., Burger, M. and T.R. Cavagnaro (2008): Roots, nitrogen transformations, and ecosystem services. Annual Review of Plant Biology 59, 341-363.

Kagata, H. and T. Ohgushi (2012): Positive and negative impacts of insect frass quality on soil nitrogen availability and plant growth. Population Ecology 54, 75-82.

Kimetu, J., Lehmann, J., Ngoze, S., Mugendi, D., Kinyangi, J., Riha, S., Verchot, L., Recha, J. and A. Pell (2008): Reversibility of soil productivity decline with organic matter of differing quality along a degradation gradient. Ecosystems 11, 726-739.

Kirkham, D. and W.V. Bartholomew (1954): Equations for following nutrient transformations in soil, utilizing tracer data. Soil Science Society of America Journal 18, 33-34.

Manzoni, S., Taylor, P., Richter, A., Porporato, A. and G.I. Ågren (2012): Environmental and stoichiometric controls on microbial carbon-use efficiency in soils. New Phytologist 196, 79-91.

Meehan, T. and R. Lindroth (2007): Modeling nitrogen flux by larval insect herbivores from a temperate hardwood forest. Oecologia 153, 833-843.

Moore, J.C., McCann, K., Heikki, S. and P.C. De Ruiter (2003): Top-down is bottom up: Does predation in the rhizosphere regulate aboveground dynamics? Ecology 84, 846-857.

Mueller, N.D., Gerber, J.S., Johnston, M., Ray, D.K., Ramankutty, N. and J.A. Foley (2012): Closing yield gaps through nutrient and water management. Nature, 254-257.
Näsholm, T., Huss-Danell, K. and P. Högberg (2000): Uptake of organic nitrogen in the field by four agriculturally important plant species. Ecology 81, 1155-1161.

Näsholm, T., Kielland, K. and U. Ganeteg (2009): Uptake of organic nitrogen by plants. New Phytologist 182, 31-48.

Ruiter, P.C.D., Moore, J.C., Zwart, K.B., Bouwman, L.A., Hassink, J., Bloem, J., Vos, J.A.D., Marinissen, J.C.Y., Didden, W.A.M., Lebrink, G. and L. Brussaard (1993): Simulation of nitrogen mineralization in the belowground food webs of two winter wheat fields. Journal of Applied Ecology 30, 95-106.

Sanchez, P.A. and B. Jama (2002): Soil fertility replenishment takes off in East and Southern Africa. In: Vanlauwe, B., Diels, J., Sanginga, N. and R. Merckx (Eds.): Integrated plant nutrient management in sub-Saharan Africa: from concept to practice. CABI, Wallingford, 23-46.

Schimel, J.P. and J. Bennett (2004): Nitrogen mineralization: Challenges of a changing paradigm. Ecology 85, 591-602.

Sutton, M.A., Oenema, O., Erisman, J.W., Leip, A., van Grinsven, H. and W. Winiwarter (2011): Too much of a good thing. Nature 472, 159-161.

Tilman, D., Cassman, K.G., Matson, P.A., Naylor, R. and S. Polasky (2002): Agricultural sustainability and intensive production practices. Nature 418, 671-677.

ul Haq, I., Mayr, L., Teal, P.E.a., Hendrichs, J., Robinson, A.S., Stauffer, C. and R. Hood-Nowotny (2010): Total body nitrogen and total body carbon as indicators of body protein and body lipids in the melon fly Bactrocera cucurbitae: effects of methoprene, a juvenile hormone analogue, and of diet supplementation with hydrolyzed yeast. Journal of Insect Physiology 56, 1807-1815.

Vondolia, K., Eggert, H. and J. Stage (2012): Nudging Boserup? The Impact of Fertilizer Subsidies on Investment in Soil and Water Conservation. Environment for Development - Discussion Paper Series, EfD DP 1208, 23 pp.

Watkins, N., Science, S. and R. Rg (1996): Gross rates of $\mathrm{N}$ mineralization associated with the decomposition of plant residues. Soil Biology 28, 169-175. 